\title{
MATHEMATICAL EQUATION TO DETERMINE THE TOTAL YIELD VALUE IN DIFFERENT INTERCROPPING SYSTEMS OF SOME VEGETABLE CROPS
}

\author{
Mahmoud A. I. Khalil* \\ Faculty of Agriculture, Zagazig University, Zagazig, Egypt \\ *Corresponding author: profkhalil37@yahoo.com Received: 15 May 2019 ; Accepted: 15 July 2019
}

\begin{abstract}
This experiment was conducted in the winter season of 2008-2009 at El-Khattara Experimental Farm, Faculty of Agriculture, Zagazig University to study the effect of different intercropping systems on the vegetative growth characters and yield, as well as to determine the total yield value of some vegetable crops, i.e. garlic (the main crop), lettuce, peas and cabbage (the secondary crops) by using mathematical equation. The obtained results showed that, all intercropping systems, i.e. garlic with lettuce, garlic with peas, and garlic with cabbage caused a significant decrease in the vegetative growth characters and total yield of all crops under study, as compared with grown each crop solely. The lowest values in this respect were move achieved via the intercropping system between garlic with cabbage, followed by garlic with lettuce. On the contrary, intercropping garlic with peas recorded less depression in this concern. With regard to the total yield value (T.Y.V.), it is quite clear from the obtained results that, all intercropping systems as described above increased the total yield value as compared with grown each crop alone. In this respect, the total yield value increased by $62.84 \%, 86.83 \%$ and $51.19 \%$ by intercropping garlic with lettuce, or peas, or cabbage, respectively.
\end{abstract}

Key words: Intercropping, yield, garlic, lettuce, peas, cabbage.

\section{INTRODUCTION}

Intercropping can be explained as a system where two or more crops species are grown in the same area of land during the growing season. The crops are not necessarily sown exactly at the same time, but they are usually simultaneous for a substantial part of their growing period. It is a simple, inexpensive strategy and has been recognized as a potentially befitted technology to increase crop production due to its substantial yield advantage than sole cropping (Ofori and Stern, 1987; Awal et al., 2006).

The cultivated area of vegetable crops is too limited corresponding with population in Egypt. Therefore, the vertical expansion in agriculture should be of great interest. This can be performed by finding out an efficient mean of changing the agriculture patterns for increasing the production per unit area, one of which is the intercroping.

Intercropping can increase yields, more deffeicently use available resources, reduce weeds, insect and disease pressure and provide greater biological and economic stability (Vandermeer, 1989).
Nowadays, intercropping vegetables within field and vegetable crops become abundant in the Egyptian agriculture.

Numerous investigators studied the effect of intercropping on the growth, yield and quality of vegetable crops, such as intercropping cucumber with lettuce (Bockstaele and Vulsteke, 1966), cucumber with taro (Behairy, 1969), Chinese cabbage with tomato (Chuo et al., 1980), lettuce or peas with pepper (El-Shamma, 1980), cabbage with tomato (Brown et al., 1985), pepper with garlic (Asandhi et al., 1987), squash with cowpea (Itulya and Oebker, 1988), okra or squash with cowpea (Abd El-Baky, 1994), strawberry with onion (ElGamilli, 1994), cucumber with taro (Fatthalla and Gawish , 1997), lettuce with garlic (Soliman, 1999), cassava with maize (Osundare and Agboola, 2003), cowpea or squash with taro (Abuzeed, 2006) and garlic or onion with mustard (Sharker et al., 2007). They concluded that, intercropping systems caused a significant decrease in the growth characters and total yield of each crop as compared with grown it alone. Moreover, they also added that 
the combined yield of the two crops in intercropping system was more than the means of the species in monoculture.

The objective of this work was to study the effect of different intercropping systems on the growth and yield of some vegetable crops, as well as to determine the total yield value of all intercropping systems under study by using mathematical equation.

\section{MATERIALS AND METHODS}

This work was conducted in the winter season of 2008-2009 at El-Khattara Experimental Farm, Faculty of Agriculture, Zagazig University (El-
Sharkia governorate), under the conditions of sandy soils to study the effect of different intercropping systems on the growth and yield of some vegetable crops, i.e. garlic, lettucr, peas and cabbage, as well as to determine the total yield value (T. Y.V.) of all intercropping systems under these study by using mathematical equation.

The physical and chemical properties of the experimental soil field are presented in Table (1).

In this experiment, garlic (Allium sativum L.) Egyptian cv. was the main crop, while lettuce (Lactca sativa L.), Balady cv., peas (Pisum sativum L.) Master -B cv., and cabbag (Brassica oleracea var. capitata L.), Zazagiz late cv., were the secondary crops (interplanted crops).

Table (1): The physical and chemical properties of the experimental soil field

\begin{tabular}{llll}
\hline \multicolumn{2}{c}{ Physical properties } & \multicolumn{2}{c}{ Chemical properties } \\
\hline Sand $(\%)$ & 95.98 & PH & 7.96 \\
Silt $(\%)$ & 2.30 & E. C. $\left(\mathrm{dsm}^{-1}\right)$ & 2.05 \\
Clay $(\%)$ & 1.27 & Total N $(\%)$ & 0.13 \\
Texture & Sandy & Available N (ppm) & 14.11 \\
& & Available P $(\mathrm{ppm})$ & 13.12 \\
& & Available K $(\mathrm{ppm})$ & 65.50 \\
\hline
\end{tabular}

This experiment included seven treatments as follows:

1- Garlic alone, in both sides of the ridge at $7 \mathrm{~cm}$ apart.

2- Lettuce alone, in both sides of the ridge at $20 \mathrm{~cm}$ apart.

3- Peas alone, in both sides of the ridge at $15 \mathrm{~cm}$ apart.

4- Cabbage alone, in on side of the ridege at $40 \mathrm{~cm}$ apart.

5- Garlic in both sides of the ridge at $7 \mathrm{~cm}$ apart, with lettuce in both sides of same ridge at $20 \mathrm{~cm}$ apart.

6- Garlic in both sides of the ridge at $7 \mathrm{~cm}$ apart, with peas in both sides of same ridge in hills at $15 \mathrm{~cm}$ apart.

7- Garlic in both sides of the ridge at $7 \mathrm{~cm}$ apart, with cabbage in one side of same ridge at $40 \mathrm{~cm}$ apart.

These treatments were arranged in complete randemize block design system with three replicates.

The plot area was $12.6 \mathrm{~m}^{2}$, and it contained three ridges with $6 \mathrm{~m}$ length, and $70 \mathrm{~cm}$ in width.

The garlic cloves, pea seeds, and the transplants of both lettuce and cabbage were planted on October

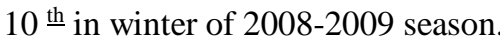

All experimental units received equal amounts of farm yard manure at a rate of $30 \mathrm{~m}^{3} /$ feddan, and calcium suprphosphate $\left(15.5 \% \mathrm{P}_{2} \mathrm{O}_{5}\right)$ at a rate of 90 $\mathrm{kg} \mathrm{P}_{2} \mathrm{O}_{5}$ per feddan at soil preparation time (before planting). In addition, both nitrogen and potassium fertilizers were added at a rate of $150 \mathrm{~kg} \mathrm{~N} /$ feddan (ammonium sulphate, $20.6 \% \mathrm{~N}$ ) and $100 \mathrm{~kg} / \mathrm{K}_{2} \mathrm{O} /$ feddan (potassium sulphate, 48-52 $\% \mathrm{~K}_{2} \mathrm{O}$ ), respectively. One third of both nitrogen and potassium fertilizers were added with farmyard manure at soil preparation time, in the center of ridge and coverd with sand. While, the two third amounts were splitted and applied weekly through irrigation water (fertigation), beginning three weeks after sowing.

The drip irrigation system was used as modified method of irrigation. The drippers were with discharge of 2 liter/h. at $1 \mathrm{bar}$. In addition, the normal agricultural practices were followed in the district.

\section{Data recorded}

\section{I: Plant growth measurements}

\section{a- Garlic plants}

A random simple of ten plants were taken from evry experimental unit at 150 days after sowing for measuring the following items:

1- Plant height $(\mathrm{cm})$.

2- Number of leaves per plant. 
3- Dry weight of leaves per plant (g).

4- Dry weight of bulb per plant (g).

5- Total dry weight of leaves and bulb (g).

\section{b- Lettuce plants}

Representative samples each of five plants, were taken by random at 75 days after transplanting from each experimental unit for measuring the plant growth characters expressed as follows:

1- Plant height (cm).

2- Number of leaves per plant.

3- Fresh weight of plant (g).

4- Dry weight of plant (g).

\section{c- Pea plants}

Random simple of five plants were taken from every experimental unit at 75 days after sowing for measuring the following data:

1- Plant height $(\mathrm{cm})$

2- Number of leaves per plant.

3- Number of branches per plant.

4- Dry weight of leaves per plant (g).

5- Dry weight of branches per plant $(\mathrm{g})$.

6- Total dry weight of leaves and branches per plant (g).

\section{d- Cabbage plants}

In representative sample of three plants taken from each experimental unit at 90 days after transplanting to measuring the following items:

1- Plant height $(\mathrm{cm})$.

2- Stem length (cm).

3- Dry weight of leaves per plant ( $\mathrm{g})$.

4-Dry weight of stem per plant $(\mathrm{g})$.

5-Total dry weight of leaves and stem per plant (g).

\section{II: Yield and its components}

a- Garlic plants

At proper maturity stage of bulbs, (180 days after sowing), bulbs of every plot were harvested, and the following data were recorded:

1- Average fresh weight of bulb (g).

2- Marketable yield (Ton/feddan*).

3- Total yield (Ton/peddan).

\section{b- Lettuce yield}

The yield and its components of lettuce plants were recarded at 95 days after transplanting as follows.

1- Average fresh weight of head ( $\mathrm{g})$.
2- Total yield (Ton/ feddan*).

\section{c- Peas yield}

To estimate the peas yield and its components at harvest time, the following data were recorded:

1- Average pod weight ( $\mathrm{g}$ ).

2- Number of pods per plant.

3- Weight of pods per plant (g).

4- Total yield (ton /feddan*).

\section{d- Cabbage yield}

The data of yield and its components of cabbage plants at harvest time (115 days after transplanting) were recorded as follows:

1- Average fresh weight of head $(\mathrm{kg})$.

2- Total yield of Heads (Ton / feddan*).

\section{III: Total yield value \% (T.Y.V.)}

The total yield value \% (T.Y.V.) of intercropping systems was determine by using mathematical equations as follows:

$$
\begin{aligned}
& \text { Yield value }(\mathrm{a})=\frac{T Y a b}{T Y a a} \times 100 \\
& \text { Yield value }(\mathrm{b})=\frac{T Y b a}{T Y b b} \times 100
\end{aligned}
$$

Total yield value of intercropping system $(\%)=$ yield value (a) + yield value (b) Were :

Yield value $(\mathrm{a})=$ Yield value of the main crop.

Yield value $(b)=$ Yield value of the secondary crop.

TYaa $=$ Total yield of the main cropr in pure stand (grown alone).

$\mathrm{TYab}=$ Total yield of the main crop (a) in intrcopping system with the secondary crop (b).

TYbb = Total yield of secondary crop (b) in pure stand (grown alone).

TYaa =Total yield of secondary (b) in intrcopping system with the main crop (a).

\section{Statistical analysis}

All collected data were subjected to statistical analysis of variance according to Sendecor and Cochran (1980)

\section{RESULTS AND DISCUSSION}

\section{Effect of intercropping systems on the growth characters}

Data presented in Table (2) showed the effect of different intercropping systems under study, i.e. garlic with lettuce, garlic with peas, and garlic with 
cabbage, on the vegetative growth characters of garlic plants, expressed as plant height, number of leaves per plant, as well as the dry weight of leaves, bulb and total dry weight per plant.

It is quite clear from such data that, all vegetative growth characters of garlic plants as describe above were significantly decreased by different intercropping systems under study, as compared with grown garlic plants alone (monoculture). In this respet, the lowest values of vegetative growth of garlic plants were recorded via the intercropping system of garlic with cabbage plants, which came in the first ranke, followed by garlic with lettuce, and garlic with peac (which recorded the less depression), respectively. In addition, such decrements in all vegetative growth parameters did not erach the level of significant in case of the intercrapping of garlic with peas as compared with growing garlic alone.

The highest depressive effect on the growth characters of garlic plants which intercropped with cabbage plants might be due to the wider blades of cabbage leaves which increases the competation for natural resources like $\mathrm{CO}_{2}$, light, soil moisture and nutrients uptake.In addition, these results might be also due to the natav of root system of all crops which intercropped with garlic plants. The root system of cabbage are lateral, which penetrated the soil deeper than that of garlic. These conditions create two level of roots penetration viz shallow fibrous roots of garlic. These conditions create tow levels of roots penetration, viz shallow fibrous roots of garlic, and beep roots of cabbage, lettuce and peas, respectively.

On the other hand, intercropping peas with garlic caused a little decrease and/ or less competition as compared with other intercropping systems, i.e. garlic with cabbage, and garlic with lettuce, respectively. This result might be attributed to that pea plants conserved more nutrients or fixed $\mathrm{N}_{2}$ to the advantage of the system and /or had less competition. Therefor, pea plants has the capacity of utilizing both soil and atmospheric nitrogen. In this concrern, Obliagwu (1995) came to simular came to similar conclucion on yam or cassava plants which intercropped with cowpea plants. Moreover, such results might be also due to that, intercropping peas with garlic resulted in a small decrease in light intensity under plants at mid plants level and its percentage of full light. Consequently, these treatments did not reflect great depression on garlic light requirement. So that, these treatment caused a little decrease on the growth characters of garlic plants. In this regard, Soliman (1999) came to similar conclusion on the intercropping systems between garlic and lettuce or squash plants.
With regard to the growth characters of lettuce, pea and cabbage plants as described in Tables $(3,4$ and 5). The obtained results in such Tables indicat that the intercropping systems between lettuce or peas or cabbage with garlic reflected significant decrease in all growth characters of such crops as compared with single planting. These results may be attributed to the competition between garlic and lettuce, or cabbage, or peas on light, water absorption and nutrients uptake.

The obtained results are in accordance with those reported by Behairy (1969) on cucumber with dasheen, El Shamma (1980) on lettuce or peas with pepper, Abd El- Baky (1994) on okra or squash with cowpea, El Gamili (1994) on strawberry with onion., and on cowpea with cassava, Fatthalla and Gawish (1997) on cucumber or cawpea with taro, Osundare and Agboola (2003) on cassava with maize and Abuzeed (2006) on cowpea or squash with taro.

From the previously presentation and discussion, it can be concluded that, all intercropping systems caused reduction effect on the growth character of garlic, lettuce, peas and cabbage, as compared with grown each crop alone.

\section{Yield and its components}

It is obvious from the results presented in Table (6) that, the average bulb weight, marketable and total yield (ton/feddan) of garlic were significantly affected by all intercropping systems under this study.

It is also quite clear from such data that, intercropping garlic with lettuce or peas or cabbage caused a marked reduction of average bulb weight, marketable and total garlic yield as compared with grown garlic alone. In this connection, the highest decrease $(30.12 \%)$ were recorded via garlic plants intercopped with cabbage plants, followed by garlic with lettuce $(22.38 \%)$ and finally garlic with peas which recoded the lowest reduction in this recpect $(4.66 \%)$.

In this connection, it could be suggested that, the highest reduction in the productivity of garlic yield by intercropping system with cabbage or lettuce might be due to the high competition between garlic and cabbage or lettuce plants on space, light, water absorption and nutrient requirements. On the contrary, the lowest reduction in the yield of garlic plants $(4.66 \%)$ which intercropped with pea plants, might be due to low competition among the two crops on different environment resources as described above. 
Khalil, M. A. I

Table (2): Effect of intercropping systems on the vegetative growth character of garlic plants at 150 days after sowing in 2008-2009 season

\begin{tabular}{|c|c|c|c|c|c|}
\hline \multirow{3}{*}{$\begin{array}{c}\text { Intercropping } \\
\text { systems }\end{array}$} & \multicolumn{5}{|c|}{ Vegetative growth characters of garlic plants } \\
\hline & \multirow{2}{*}{$\begin{array}{l}\text { Plant height } \\
\quad(\mathrm{cm})\end{array}$} & \multirow{2}{*}{$\begin{array}{l}\text { Number of } \\
\text { leaves/plant }\end{array}$} & \multicolumn{3}{|c|}{ Dry weight/plant (g) } \\
\hline & & & Leaves & Bulb & Total \\
\hline Garlic alone & 89.18 & 11.16 & 8.44 & 10.04 & 18.48 \\
\hline Garlic + Lettuce & 77.67 & 8.66 & 6.90 & 8.51 & 15.41 \\
\hline Garlic + Peas & 84.59 & 10.54 & 8.02 & 9.72 & 17.74 \\
\hline Garlic + cabbage & 72.01 & 7.57 & 6.33 & 7.65 & 13.97 \\
\hline L.S.D. at 0.05 level & 5.13 & 1.52 & 0.54 & 0.71 & 1.20 \\
\hline
\end{tabular}

Table (3): Effect of intercropping systems on the vegetative growth character of lettuce plants at 75 days after transplanting in 2008-2009 season

\begin{tabular}{|c|c|c|c|c|}
\hline \multirow{3}{*}{$\begin{array}{c}\text { Intercropping } \\
\text { systems }\end{array}$} & \multicolumn{4}{|c|}{ Vegetative growth characters of lettuce plants } \\
\hline & \multirow{2}{*}{$\begin{array}{l}\text { Plant height } \\
(\mathrm{cm})\end{array}$} & \multirow{2}{*}{$\begin{array}{l}\text { Number of } \\
\text { leaves/plant }\end{array}$} & \multicolumn{2}{|c|}{ Head weight ( $\mathrm{g}$ ) } \\
\hline & & & Fresh & Dry \\
\hline Lettuce alone & 42.23 & 47.99 & 527.68 & 26.56 \\
\hline Lettuce + Garlic & 34.60 & 37.75 & 412.90 & 21.26 \\
\hline L.S.D. at 0.05 level & 5.27 & 6.35 & 64.85 & 2.94 \\
\hline
\end{tabular}

Table (4): Effect of intercropping systems on the vegetative growth characters of pea plants at 75 days after sowing in 2008-2009 season

\begin{tabular}{lcccccc}
\hline \multirow{2}{*}{\begin{tabular}{c} 
Intercropping \\
\multicolumn{1}{c}{ systems }
\end{tabular}} & $\begin{array}{c}\text { Plant height } \\
(\mathrm{cm})\end{array}$ & \multicolumn{2}{c}{ Number /plant } & \multicolumn{2}{c}{ Dry weight/plant $(\mathrm{g})$} \\
\cline { 2 - 7 } & & Branch & Leaves & Branch & Leaves & Total \\
\cline { 3 - 7 } & 76.97 & 5.54 & 25.68 & 3.71 & 6.27 & 9.98 \\
Peas alone & 68.74 & 4.28 & 21.49 & 3.16 & 5.43 & 8.59 \\
Peas + Garlic & 6.18 & 1.02 & 3.14 & 0.35 & 0.47 & 0.82 \\
L.S.D. at 0.05 level & & & & & &
\end{tabular}

Table (5): Effect of intercropping systems on the vegetative growth characters of Cabbage plants at 90 days after transplanting in 2008-2009 season

\begin{tabular}{lccccc}
\hline & \multicolumn{5}{c}{ Vegetative growth characters of cabbage plants } \\
\cline { 2 - 6 } \multicolumn{1}{c}{ Intercropping } & \multicolumn{3}{c}{ Dry weight/plant (g) } \\
\cline { 2 - 6 } & $\begin{array}{c}\text { Plant height } \\
(\mathrm{cm})\end{array}$ & $\begin{array}{c}\text { Stem } \\
\text { length } \\
(\mathrm{cm})\end{array}$ & Total & Total & Total \\
\cline { 4 - 6 } & 75.11 & 28.96 & 50.60 & 289.35 & 339.95 \\
Cabbage alone & 61.05 & 21.81 & 41.52 & 253.29 & 294.81 \\
Cabbage + Garlic & 6.52 & 5.60 & 4.61 & 15.43 & 27.54 \\
\hline
\end{tabular}


On the other hand, with regard to the yield and its components of different crops i.e. lettuce, or peas, or cabbage intercropped with garlic plant, the obtained data in Tables ( 7,8 and 9) clearly inicated that, average head weight and total yield / feddan of both lettuce and cabbage significantly decreasr by intercropping with garalic, as compared with single planting of each. The reduction in total yield of lettuce and cabbage was $18.65 \%$ and $14.69 \%$, respectively, when intercropped with garlic plants. These resultus may be attributed to the competition between garlic and lettuce or cabbage on environmental resources (light, water absorption and nutrients uptake).Also such reduction in yield was directly connected with the reduction in vegetative growth ( Tabels 3,4 and 5 ).

Moreover, the yield and its component of pea plants expressed as, average pod wight, number and weight of pods per plant, as well as total pods yield per feddan were decreased when pea plants intercropped with garlic plants, as compared with the single planting of pea plants. The reduction in total yield of peas intercropped with garlic was $8.41 \%$.This value was less than those obtained in itercropping both cabbage or lettuce with garlic.

The reduction in total yield of pea plants when interrcopped with garlic might be attributed to the nitrogen translocation from peas to garlic plants. In this regard, Askar et al.(1997) came to similar conclusion.

The obtained results were in agreement with those reported by Bockstaele and Vulsteke (1966) on french bean with onion, Behairy (1969) on cucumber with dasheen, Chuo et al. (1980) on cabbage with tomato, El- Shamma (1980) on pea or lettuce with pepper, Brown et al. (1985) on cabbage with tomato, Itulya and Oebker (1988) on squash with cowpea, Asandhi et al. (1987) on pepper with garlic, Abd El- Baky (1994) on okra or squash with cowpea, Soliman (1999) on lettuce with garlic, EL-
Gizy (2001) on bean with pepper or eggplant, Abuzeed (2006) on cowpea or sqush with taro, and Sharker et al. (2007) on garlic or onion with mustard.

Generally, from the above mentioned result and discussion it is worthy to notice that all intercropping systems caused a marked reduction on the yield and its components in the crops under these study, as compered with the single planting of each crop.

\section{Total yield value (T.Y.V.)}

It is evident from data illustrated in Table (6) and Fig.(1) that all intercropping systems under these study caused a significant and marked effect on the total yield value (\%) as compared with the monoculture of each crop. Whereas, the highest values in this respect were more distinct via intercropping garlic with peas, which came in the first rank.In addition, intercropping garlic with lettuce came in the second rank, followed by garlic with cabbage, respectively.

The total yield value increases by $62.84 \%$, $86.83 \%$ and $51.19 \%$, when intercropping lettuce or peas or cabbage with garlic, respectively. A yield advantage occur heirn might be due to the differences in rooting system of either garlic plants or companion crops, nutrient requirements and efficiency of photosynthesis process. Thus, they are able to make better overall use of environmental resources when grown in combination than grown separately. In this connection, Fatthallah and Gawish (1997) and Abuzeed (2006) came to similar conclusion.

Finally, from the aforementioned results and discussion it could be generally suggested that all intercropping systems under these study as described above, were more effective on increasing total yield value, as compared with solo cropping.

Table (6): Effect of intercropping systems on the yield and total yield value of garlic plants in 2008-2009 season

\begin{tabular}{|c|c|c|c|c|}
\hline \multirow{3}{*}{$\begin{array}{c}\text { Intercropping } \\
\text { systems }\end{array}$} & \multicolumn{3}{|c|}{ Garlic yield } & \multirow{3}{*}{$\begin{array}{l}\text { Total yield } \\
\text { value } \\
(\%)\end{array}$} \\
\hline & \multirow{2}{*}{$\begin{array}{c}\text { Average bulb } \\
\text { weight (g) }\end{array}$} & \multicolumn{2}{|c|}{ Yield (Ton/ feddan) } & \\
\hline & & Marketable & Total & \\
\hline Garlic alone & 83.16 & 10.484 & 10.967 & 100.00 \\
\hline Garlic + Lettuce & 67.22 & 7.490 & 8.510 & 162.84 \\
\hline Garlic + Peas & 78.84 & 9.657 & 10.453 & 186.83 \\
\hline Garlic + Cabbage & 59.74 & 6.350 & 7.662 & 151.19 \\
\hline L.S.D. at 0.05 level & 5.39 & 0.480 & 0.652 & 6.65 \\
\hline
\end{tabular}


Khalil, M. A. I

Table (7): Effect of intercropping systems on the yield and total yield value of lettuce plants in 2008-2009 season

\begin{tabular}{lccc}
\hline \multirow{2}{*}{$\begin{array}{c}\text { Intercropping } \\
\text { systems }\end{array}$} & \multicolumn{2}{c}{ Lettuce yield } & Total yield value \\
\cline { 2 - 3 } & $\begin{array}{c}\text { Average head } \\
\text { weight }(\mathrm{g})\end{array}$ & $\begin{array}{c}\text { Total Yield } \\
\text { (Ton/ feddan })\end{array}$ & $\begin{array}{c}\text { ( }) \\
\text { Lettuce alone }\end{array}$ \\
Lettuce + Garlic & 698.22 & 27.947 & 100.00 \\
L.S.D. at 0.05 level & 580.73 & 23.841 & 8.84 \\
\hline
\end{tabular}

Table (8): Effect of intercropping systems on the yield and total yield value of pea plants in 2008 - 2009 season

\begin{tabular}{|c|c|c|c|c|c|}
\hline \multirow{3}{*}{$\begin{array}{c}\text { Intercropping } \\
\text { systems }\end{array}$} & \multicolumn{4}{|c|}{ Peas Yield } & \multirow{3}{*}{$\begin{array}{l}\text { Total yield } \\
\text { value } \\
(\%)\end{array}$} \\
\hline & \multicolumn{3}{|c|}{ Yield / plant } & \multirow{2}{*}{$\begin{array}{c}\text { Total Yield } \\
\text { (Ton/ } \\
\text { feddan) }\end{array}$} & \\
\hline & $\begin{array}{c}\text { Average head } \\
\text { weight }(\mathrm{g})\end{array}$ & $\begin{array}{l}\text { Numer of } \\
\text { pods }\end{array}$ & $\begin{array}{c}\text { Weight of } \\
\text { pods }(\mathrm{g})\end{array}$ & & \\
\hline Peas alone & 7.19 & 8.28 & 59.53 & 4.781 & 100.00 \\
\hline Peas + Garlic & 6.63 & 7.34 & 48.66 & 4.379 & 186.83 \\
\hline L.S.D. at 0.05 level & 0.58 & 0.87 & 6.12 & 0.320 & 7.15 \\
\hline
\end{tabular}

Table (9): Effect of intercropping systems on the yield and total yield value of cabbage plants in 2008 -2009 season

\begin{tabular}{|c|c|c|c|}
\hline \multirow{2}{*}{$\begin{array}{c}\text { Intercropping } \\
\text { systems }\end{array}$} & \multicolumn{2}{|c|}{ Cabbage yield } & \multirow{2}{*}{$\begin{array}{c}\text { Total yield } \\
\text { value } \\
(\%)\end{array}$} \\
\hline & Average head weight (g) & $\begin{array}{l}\text { Total Yield } \\
\text { (Ton/ feddan) }\end{array}$ & \\
\hline Cabbage alone & 5.937 & 49.138 & 100.00 \\
\hline Cabbage + Garlic & 4.901 & 39.975 & 151.19 \\
\hline L.S.D. at 0.05 level & 0.270 & 3.541 & 10.27 \\
\hline
\end{tabular}

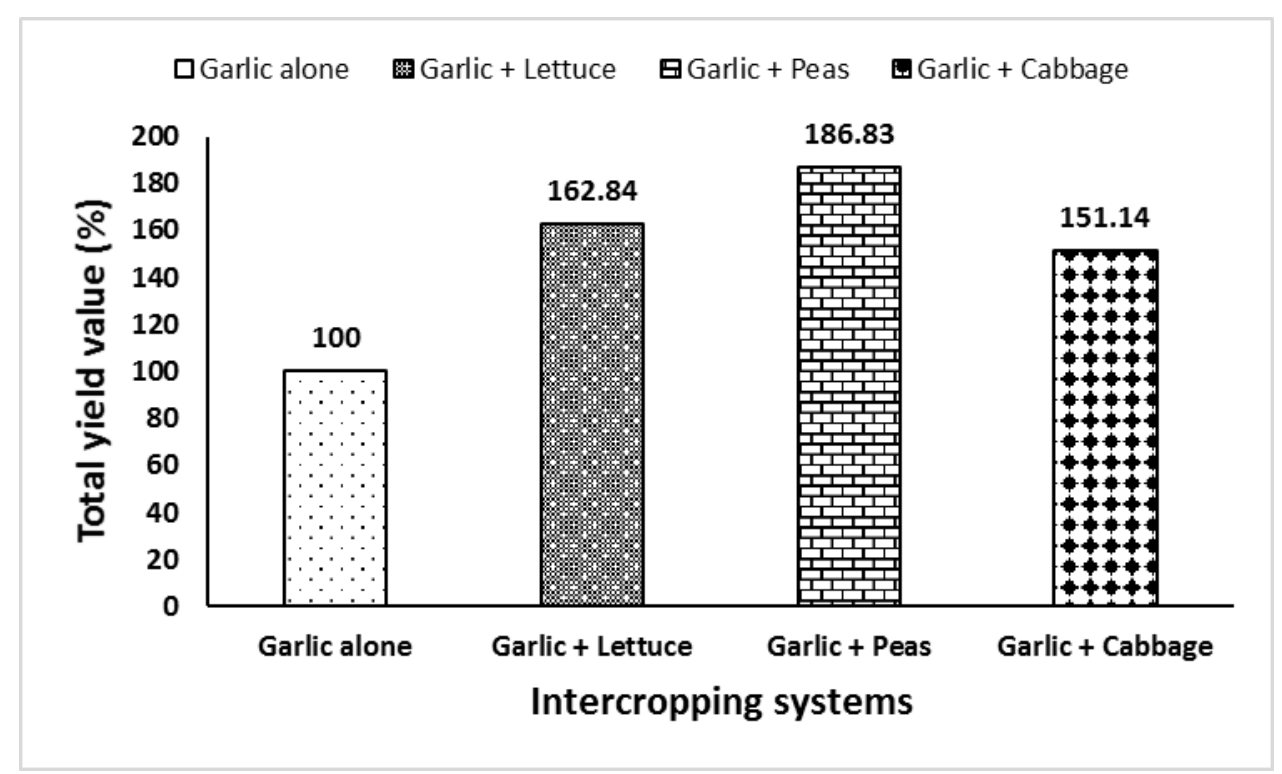

Fig. (1): Effect of different intercropping systems on total yield value (\%) 


\section{REFERENCES}

Abd El-Baky, M.M.H. (1994). Effect of intercropping on growth and productivity of some vegetable plants. M.Sc. Thesis, Fac. Agric, Ain Shamas Univ., Egypt.

Abuzeed, A.M.M. (2006). Effect of intercropping on growth and quality of taro and some other vegetables. M.Sc. Thesis, Fac. Agric., Ain Shams Univ., Egypt.

Asandhi, A.A.; Gunadi, N. and Wijaya, A. (1987). Effect of intercropping of garlic and red pepper on growth, yield and land productivity. Bull. Penelition Horikultura, 15 (1): 79-84 (C.F.Hort. Abstr., 59: 9004).

Askar, El.S.H.; El- Bary, F.A. and El-Gizy, S.M. (1997). Effect of some intercropping systems on the vegetative growth, productivity and yield components of cucumber and dry bean. J.Agric. Sci., Mansoura Univ., 22 (7): 2366: 2386, Egypt.

Awal, M.A.; Kothi, H. and Ikeda, T. (2006). Radiation in - terception and use by maize/ peanut intercrop canopy. Agric. For Meteroral, 139:73-84.

Behairy, A.G. (1969). Effect of interplanting some vegetable plants in dasheen ridges on competition between them. Ph. D. Thesis, Fac. Agric., Ain Shams Univ., Egypt.

Bockstaele, L. and Vulsteke, G. (1966). Intercrops for asparagus. Tuinbouwberichten, 30: 120-122 (C.F. Hort. Abstr., 36:6508)

Brown, J.E.; Splittstoesser, W.E. and Gerber, J.M. (1985). Production and economic returns of three vegetable double cropping systems. J. Amer. Soc. Hort. Sci., 110:414-417.

Chuo, S.K.; Wong, S.H. and Leong, P.C. (1980). Astudy of possibility of intercropping chye sim (Brassica chinensis) with tomato (Lycopersicon esculentum) and the effect on their yield in Singapore. Singapore J. Piramary Industries, 8 (2), 91-102 (C.F. Hor. Abstr., 61:2481).

El-Gamili, A. E. (1994). Studies on intercropping of onion with some vegeteable crops. Menofiya J. Agric Res., 19 (1): 581-595.
El-Gizy, S.M. (2001). Intercropping of bean with pepper or eggplant increased productivity. Egypt. J. Hort., 28 (1): 27-40.

El-Shamma, H.A. (1980). Studies on the effect of intercropping of some vegetable crops. M.Sc. Thesis, Fac. Agric, Zagazig Univ., Egypt.

Fatthallah, M.A. and Gawish, R.A. (1997). Effect of taro intercropping with some vegetable crops on growth, yield and land productivity in relation to several soil moisture regimes. Menofiya J. Agric. Res., 22 (6): 1647-1675.

Itulya, F.A. and Oebker, F.N. (1988). The effect of intercropping, nitrogen and phosphorus fertilizer levels on yield of mung bean (Vigna radiate L. Welezck) and summer squash (Cucurbita pepo, L). East African Agric. and foresty J., 51(2): 66-70 (C.f. Hort. Abstr., 59: 274).

Obliagwu, C.T. (1995). Estimated yield and nutrient contribution of legume cover crops intercropped with yam, cassava and maize in the Benue. River Basins of Nigeria. J. Plant Nutr., 18 (2): $2775-2782$.

Ofori, F. and Stern, W.R. (1987). Cereal- legume intercropping systems. Adv. Agron., 41:41-90.

Osundare, B. and Agboola, A. A. (2003). Effect of different companion crops on the performance of cassava. Moor. J. Agric Res., 4 (1): 50-53.

Sharker, P.R.; Rahaman, M.M. and Das, B.C. (2007). Effect of intercropping of mustard with onion and garlic on Aphid population and yield. J. Bio. Sci., 15: 35-40.

Snedecor, G.W. and Cochran, W. G. (1980). Statistical method. 7 th Ed., Iowa State Univ. Press, Ames Iowa, USA.

Soliman, M.F.Z. (1999). Studies on intercropping some vegetable crops on garlic plants. M.Sc. Thesis, Fac. Agric., Cairo Univ., Egypt.

Vandermeer, J. (1989). The ecology of intercropping. Cambridge Univ. Press, England. 